\title{
Copepoda (Crustacea) associated with commercial and non-commercial Bivalvia in the East Scheldt, The Netherlands
}

\author{
Jan H. Stock \\ c/o Institute of Taxonomic Zoology, University of Amsterdam, P.O. Box 4766, 1009 AT Amsterdam, \\ The Netherlands
}

Keywords: Bivalvia, parasitic Copepoda, Netherlands

\begin{abstract}
Six species of Copepoda Poecilostomatoida of the families Myicolidae, Sabelliphilidae, Lichomolgidae, and Mytilicolidae are recorded from six different species of intertidal bivalves in the East Scheldt (The Netherlands), a branch of the southern bight of the North Sea. One bivalve species may harbour more than one species of copepod, and one copepod species may use more than one species of bivalves as host.

Mytilicola orientalis and Myicola ostreae are new to the North Sea, both being undoubtedly carried in accidentally with oriental oysters, successfully introduced for mariculture. In the light of the damage that was caused by Mytilicola intestinalis to Dutch mussel cultures in the past, the acclimatization of $M$. orientalis is a matter of concern, the more so since it infests not only its original oriental host, Crassostrea gigas, but also the native European species, Ostrea edulis and Mytilus edulis, both important fisheries resources in the East Scheldt region.
\end{abstract}

\section{Material and methods}

During the period May to September 1992, bivalves were regularly (3 times a week) collected in the East Scheldt, on the south coast of the island of Schouwen, at a locality called Schelphoek. The centre of the area bears the coordinates $45.500 \times 413.000$ on the topographic map of the Netherlands, sheet 42 , scale 1:50,000 (Topographical Service, Emmen, 1986), which corresponds roughly with $51^{\circ} 33^{\prime} \mathrm{N} 03^{\circ} 36^{\prime} \mathrm{E}$. The area is semienclosed by two dams, fully marine, but protected against rough seas. The tidal difference during spring tides may amount to 3 m or more. Its western part consists of gravel and boulders; the central and eastern parts are intertidal flats of sandy mud and fine sand. At low spring tides, extensive oyster beds are exposed, mainly inhabited by wild specimens of the acclimatized oriental oyster, Crassostrea gigas.

The bivalve species encountered, and their copepod associates, are shown in Table $\mathbf{I}$.
The shells were opened and the animal's soft parts were taken out and placed for some 12 hours in a mixture of $95 \%$ seawater and $5 \%$ ethyl alcohol. The fluid was then filtered through a 300 $\mu \mathrm{m}$ sieve and the copepods were picked from the retained sediment under a dissecting microscope. Specimens were studied in glycerine or lactophenol and dissections were stored as permanent mounts in Reyne's modification of Faure's medium.

Representative sets of each species have been placed in the Zoölogisch Museum of the University of Amsterdam.

\section{Results}

The following copepods and host molluscs were found:

\section{Family MYicolidaE}

\section{Myicola ostreae Hoshina \& Sugiura, 1953}

Material. - Nine specimens from Crassostrea gigas and two specimens from Ostrea edulis (collected over the entire period of observation).

This copepod has no doubt been accidentally introduced into Dutch waters with oriental oysters. It is uncommon, though actively reproducing, both in $C$. gigas and $O$. edulis (the latter being a new host for the species). These are the first records for $M y i$ cola ostreae in the North Sea; the species comes originally from Japanese and Korean waters.

The generic status of this copepod has been discussed by Humes (1986), who suggested to remove 
M. ostreae to the genus Ostrincola, but for the moment I follow Ho \& Kim (1991) and consider the multiseriate ovisac a key character for Myicola.

\section{Family SABELLIPHILIDAE}

Herrmannella rostrata Canu, 1891

Material. - Five specimens in branchial chamber of Mya arenaria, many specimens in branchial chamber of Scrobicularia plana, and many specimens in branchial chamber of Cerastoderma (formerly Cardium) edule.

Although this copepod is known from at least 11 different bivalve hosts (Humes \& Stock, 1973), it was not recorded before from Mya arenaria and Scrobicularia plana. Avdeev (1987) records a species of Herrmannella, $H$. dentata, from Mya japonica in the Sea of Japan, but I contented myself that the Dutch material from $M y a$ belongs to $H$. rostrata and not to $H$. dentata.

Herrmannella duggani Holmes \& Minchin, 1991, recently described from Ostrea edulis from Ireland and Brittany, has not been encountered during our study.

In The Netherlands, $H$. rostrata occurs predominantly in the Cockle, Cerastoderma edule, but has also been found (Stock, 1965) in Macoma balthica (Linnaeus, 1758) and Spisula subtruncata (Da Costa, 1778).

Modiolicola insignis Aurivillius, 1882

Material. - Many specimens from the gills of Mytilus edulis.

This small copepod, with its distinctive pink colour, is common in the Boreal region of Europe, and is already known from The Netherlands (Stock \& De Vos, 1960: 206; Stock, 1965: 67).

\section{Family LichomolgidAE}

Macrochiron fucicolum Brady, 1872

Material. - Two females from the gills of Crassostrea gigas.
The real host of this copepod is somewhat of a mystery; it is supposed to live on (feed on?) brown algae. At any rate only two specimens of this copepod were found in Crassostrea gigas, which seems to indicate that this occurrence must be considered accidental.

The species was already known from The Netherlands (Stock, 1957: 380; Stock \& De Vos, 1960: 206).

\section{Family Mytilicolidae}

Mytilicola intestinalis Steuer, 1902

Material. - Many specimens from the guts of Mytilus edulis.

This copepod has been known from The Netherlands since the early fifties (Korringa, 1950; 1951), when it caused considerable damage to mussel fisheries and cultures. In the course of the years, the intensity of the infestations declined to such a level that no serious harm occurs anymore. At the maximum of the epidemic, $M$. intestinalis was sparingly encountered in other mollusc hosts as well (Ostrea edulis and the gastropod Crepidula fornicata (Linnaeus, 1758); Stock, 1965). During our 1992 survey no Mytilicola intestinalis was found in these two hosts. In Mytilus edulis from Schelphoek, $M$. intestinalis is more common than the following species, $M$. orientalis.

Steuer published the combination Mytilicola intestinalis n. gen., n. sp. twice $(1902,1905)$; the first year takes priority of course.

\section{Mytilicola orientalis Mori, 1935}

Material. - Many specimens from the gut of Crassostrea gigas; many specimens from the gut of Ostrea edulis; some specimens from the gut of Mytilus edulis.

No doubt this species, like Myicola ostreae, has been introduced accidentally into Europe (and elsewhere, e.g., on the Pacific coast of the U.S.A., where it was at first considered a different species, $M$. ostreae Wilson, 1938) with oriental oysters, Crassostrea gigas. In Schelphoek, C. gigas nowa- 
Table I. Commercial (marked with ${ }^{*}$ ) and non-commercial species of Bivalvia encountered at Schelphoek (East Scheldt) and their copepod associates, if any. Note that the clam, Mya arenaria. is a commercial species along the North American East coast, but is not exploited in The Netherlands.

\begin{tabular}{ll}
\hline Host & Copepod \\
\hline${ }^{*}$ Crassostrea gigas & Mytilicola orientalis \\
(Thunberg, 1793) & Mori, 1935 \\
& Myicola ostreae Hoshina \& \\
& Sugiura, 1953 \\
& Macrochiron fucicolum \\
& Brady, 1872 \\
${ }^{*}$ Ostrea edulis Linnaeus, & Mytilicola orientalis \\
1758 & Myicola ostreae \\
${ }^{*}$ Mytilus edulis (Linnaeus, & Mytilicola intestinalis \\
$1758)$ & Steuer, 1902 \\
& Mytilicola orientalis \\
& Modiolicola insignis \\
(*)Mya arenaria Linnaeus, & Aurivillius, 1882 \\
1758 & Herrmannella rostrata \\
${ }^{*}$ Cerastoderma edule (Linnaeus, & Canu, 1891 \\
$1758)$ & Herrmannella rostrata \\
Scrobicularia plana & \\
(Da Costa, 1778) & Herrmannella rostrata \\
Angulus tenuis (Da Costa, 1778) & no copepods \\
Teredo navalis Linnaeus, 1758 & no copepods \\
\hline
\end{tabular}

days outnumbers the indigenous oyster, Ostrea edulis. Both oyster species are heavily infested by $M$. orientalis; lower infestation percentages occur in the blue mussel, Mytilus edulis. Both Ostrea edulis and Mytilus edulis are new hosts for M. orientalis. Moreover, these are the first records of $\boldsymbol{M}$. orientalis for the North Sea area; the species originates from Japan and Korea.

The distinctions between $M$. intestinalis and $M$. orientalis are best shown by Ho \& Kim (1992). $M$. intestinalis has strongly diverging caudal rami, shorter ovisacs, and less pointed, less divergent, lateral body processes.

\section{Discussion}

The East Scheldt is a branch of the southern North Sea with several peculiar ecological characteristics. The area is fully marine, with very little inflow of fresh water, but more important in parasitological respect is the fact that much of its waters never leave the embayment. The water moves seaward during low tide, inland again during high tide, going forth and back in a kind of shuttle movement. Infesting larval stages of parasitic or associated copepods thus stay inside the East Scheldt, increasing the chance of finding a suitable host. This makes the East Scheldt vulnerable to booms in infestation rates, but on the other hand very suitable for mariculture, in particular of oysters, whose larvae settle in the area in which they were produced.

In the early fifties, an epidemic caused by the copepod Mytilicola intestinalis caused great damage to the commercial activities around the catch and production of the blue mussel, Mytilus edulis (see Korringa, 1950; 1951). The discovery, during the present study, of the presence of an acclimatized population of the copepod Mytilicola orientalis in the East Scheldt therefore is alarming. As said above, the copepod was no doubt introduced accidentally in the East Scheldt, through importation of the oriental oyster, Crassostrea gigas, which "escaped" from mariculture and now forms large banks in the wild. Not only its original oriental host is infested, but the copepod invaded also the indigenous bivalves, Ostrea edulis and Mytilus edulis. It remains to be seen if Mytilicola orientalis will turn out to be as noxious as its congener, $M$. intestinalis. At any rate, cautious observations of the development of Mytilicola infestations seem justified.

Of the other alien copepod introduced with oriental oysters, Myicola ostreae, no harmful effects are known, but this associate should be followed as well, especially since it has proved to infest not only its original host, Crassostrea gigas, but also indigenous oysters, Ostrea edulis. At present, it occurs in numbers too low to form an economic risk.

The remaining copepod associates are endemic to the Boreal region, and are not known to cause any noticeable damage.

\section{Acknowledgments}

The author is indebted to Mr. R.G. Moolenbeek, keeper of Malacology at the Zoölogisch Museum Amsterdam, for the 
identification of the material of Crassostrea gigas, and for nomenclatorial advice on the actual names of the bivalve hosts.

\section{References}

Avdeev, G.V., 1987. [Two new copepod species (Sabelliphilidae, Poecilostomatoida) from bivalvian molluscs in the Peter the Great Bay of the Japan Sea]. Zool. Zh., 66(4): 608-613 [in Russian, English summary].

Ho, J.-S. \& I.H. Kim, 1991. Copepod parasites of commercial bivalves in Korea, II. Copepods from cultured bivalves. Bull. Korean Fish. Soc., 24(6): 369-396.

Ho, J.-S. \& I.H. Kim, 1992. Copepod parasites of gastropods from Korea. Korean J. Zool., 35: 240-255.

Holmes, J.M.C. \& D. Minchin, 1991. A new species of Herrmannella (Copepoda, Poecilostomatoida, Sabelliphilidae) associated with the oyster Ostrea edulis L. Crustaceana, 60(3): 258-269.

Humes, A.G., 1986. Myicola metisiensis (Copepoda: Poecilostomatoida), a parasite of the bivalve Mya arenaria in eastern Canada, redefinition of the Myicolidae, and diagnosis of the Anthessidae n. fam. Can. J. Zool., 64: 1021-1033.

Humes, A.G. \& J.H. Stock, 1973. A revision of the family
Lichomolgidae Kossmann, 1877, cyclopoid copepods mainly associated with marine invertebrates. Smithson. Contr. Zool., 127: i-v, 1-368.

Korringa, P., 1950. De aanval van de parasiet Mytilicola intestinalis op de Zeeuwse mosselcultuur. Visserij-Nieuws, 7 (Suppl.): 1-7.

Korringa, P., 1951. Over Mytilicola intestinalis (Copepoda parasitica) en enkele andere ongewenste vreemdelingen in onze wateren. Vakbl. Biol., 31(4): 63-74.

Steuer, A., 1902. Mytilicola intestinalis n. gen. n. sp. aus dem Darm von Mytilus galloprovincialis Lam. Zool. Anz., 25: 635-637.

Steuer, A., 1905. Mytilicola intestinalis n. gen. n. sp. Arb. zool. Inst. Univ. Wien, 15(1): 1-46, Pls. I-V.

Stock, J.H., 1957. Some notes on the genus Macrochiron Brady, 1872 (Copepoda, Cyclopoida). Ann. Mag. nat. Hist., (12)10: 378-382.

Stock, J.H., 1965. On Copepoda associated with Dutch molluscs. Basteria, 29: 65-71.

Stock, J.H. \& A.P.C. de Vos, 1960. Einige wirbellose Tiergruppen des Dollard-Ems-Estuariums. Verh. K. ned. geol. mijnb. Genoot., (Geol.) 19: 203-220.

Received: 31 January 1993 